\title{
TTR
}

Traduction, terminologie, re?daction

\section{Lynne Bowker. Computer-Aided Translation Technology: A Practical Introduction, Ottawa, Didactics of Translation Series, University of Ottawa Press, 2002, 185 p.}

\section{Candace Séguinot}

Volume 15, numéro 2, 2e semestre 2002

Censure et traduction dans le monde occidental

Censorship and Translation in the Western World

URI : https://id.erudit.org/iderudit/007488ar

DOI : https://doi.org/10.7202/007488ar

Aller au sommaire du numéro

Éditeur(s)

Association canadienne de traductologie

ISSN

0835-8443 (imprimé)

1708-2188 (numérique)

Découvrir la revue

Citer ce compte rendu

Séguinot, C. (2002). Compte rendu de [Lynne Bowker. Computer-Aided Translation Technology: A Practical Introduction, Ottawa, Didactics of Translation Series, University of Ottawa Press, 2002, 185 p.] TTR, 15(2), 239-241. https://doi.org/10.7202/007488ar d'utilisation que vous pouvez consulter en ligne.

https://apropos.erudit.org/fr/usagers/politique-dutilisation/ 
C'est pourquoi, retournant à la question typologique des trois types fondamentaux, je préfère, d'une part, substituer texte littéraire à texte expressif et, d'autre part, considérer l'expressivité comme un contenu informant sur l'auteur du texte (intentionnellement: ce qu'il écrit pour exprimer sa réaction personnelle au sujet traité dans son texte, ou involontairement : ce qui transparaît de lui dans le texte, par exemple son origine sociale ou géographique). Un contenu dont il faut, comme toujours, évaluer la pertinence à partir de la finalité accordée au texte d'arrivée.

Appliquée à La critique des traductions, la méthode de Katharina Reiss conduit à une évaluation élogieuse du travail de sa traductrice, Catherine Bocquet, qui a su rendre avec beaucoup de lisibilité une étude restée pendant trente ans " lettre close pour les francophones non germanistes ", n'hésitant pas à l'actualiser et à la naturaliser par d'abondants commentaires (une quarantaine de [NdT] sur près de 300 notes de bas de page).

Si cette étude, par la somme des connaissances qu'elle contient ainsi que par la rigueur de ses analyses, s'adresse bien en priorité aux spécialistes, je voudrais cependant suggérer qu'elle pourra convenir tout aussi bien aux traducteurs novices, auxquels elle rendra l'inestimable service de les conduire à plus de lucidité devant les nombreux obstacles qu'on rencontre dans la pratique de la traduction.

Claude Tatilon, Collège Glendon, Université York

Lynne Bowker. Computer-Aided Translation Technology: A Practical Introduction, Ottawa, Didactics of Translation Series, University of Ottawa Press, 2002, 185 p.

When I have a question about computer applications and translation and I need a quick and dirty answer, I call Lynne Bowker. Like other teachers of translation and practising translators, I have come to respect her understanding of the technologies and the pros and cons of integrating them into a translation program. This is not in itself a textbook for use in a course on computer aids to translation, though it could probably serve that purpose: it is, as it advertises itself, an introduction to the products and applications that translators may need 
to know about, if not use. It is simple enough to be read by any student who has yet to think about sending a text electronically, and interesting enough to serve as a kind of consumer guide for anyone wanting to know more about the limits of their particular hardware or software or simply to understand the basic issues that technology has been trying to address in this field. There is an excellent comparison of the features, the drawbacks, and the system requirements for software available in each of the areas of computer applications used to assist translation in a separate appendix (pp. 157-174).

In the Introduction, Bowker clearly delimits the approach the book will take: a focus on the tools to present text in machine-readable form, translation memory, term-extraction tools and corpus-analysis tools. For applications that are useful to translators but which are broader in scope such as word processing and grammar checking programs and Internet searches, she sends readers to relevant authors (p. 6). There are six chapters in all. The first, Why Do Translators Need to Learn about Technology, suggests some interesting new reasons in addition to the obvious, for example the potential for studying student interaction with technology with the aim of rethinking translation pedagogy and the need for students to face the limitations that are imposed by working with technology. One example of the latter is the importance of thinking out the form in which data will be stored for later access, another the arbitrary limits that block machines but not humans in processes of text analysis and recognition.

Chapter 2, Capturing Data in Electronic Form, explains how scanning and voice recognition software work and how file formats constrain the compatibility of software. The tables on pages 40-41 documenting specific conversion problems could be particularly helpful. The third chapter, on Corpora and Corpus-Analysis Tools, looks at the applications that are used to compile word frequency lists, collocations, and monolingual and bilingual concordances. As is the case with the book in general, the organization of the chapter is around the knowledge available in the field as opposed to a focus on skill development. What this means in practical terms is that different readers with different needs will find themselves searching a bit for what is relevant to them. For example, a teacher of undergraduate translation students will find that she does address the value of using concordances, but rather late in the chapter (p. 71). Before that come topics of interest to people using these tools for research or wanting to understand the bridge between tools for linguistic and comparative 
linguistic analysis, like stop lists and lemmatization (pp. 51-52). Because so much of the comparative information is grouped into tables, readers will find themselves referred to sections elsewhere in the book. This makes the book particularly useful as a reference, a little more work as a stand-alone text for student use in class.

The next chapter, Terminology-Management Systems, reviews the benefits and drawbacks of working with a specific term management package and points out the potential for sharing terminology over a network. Chapter 5 on Translation-Memory Systems looks at the kinds of systems available and the kinds of texts that are suitable for this kind of treatment. The last chapter, Other New Technologies and Emerging Trends, deserves a better title because the topics that it covers are key and rarely treated. One is the problem of separating out the words to be translated from the code in a document that is marked up for publication on the web, the second is the need to manage the translation cycle in a way that has changed with multilingual text production.

In addition to an up-to-date bibliography, the book ends with two appendices, one a glossary of technical terms, the other, Appendix $\mathrm{B}$, a comparison of available translation-oriented tools of the kinds discussed in the text itself. A very useful addition to any translator's library.

Candace Séguinot School of Translation, Glendon College York University

Chapdelaine, Annick et Gillian Lane-Mercier (dir.) Faulkner. Une expérience de retraduction. Les Presses de l'Université de Montréal, 2001, $183 \mathrm{p}$.

This volume consists of three essays and a substantial introduction describing the theories and procedures underlying the McGill University-based GRETI (Groupe de recherche en traductologie) in (re)translating William Faulkner's The Hamlet. It also includes a chapter presenting the end-product of the project, the (re)translation of Faulkner's narrative itself. 